\title{
Time Well Spent is not the Time Wasted: A Study from the Pandemic
}

\section{OPEN ACCESS}

Manuscript ID:

ECO-2021-09044123

Volume: 9

Issue: 4

Month: September

Year: 2021

P-ISSN: 2319-961X

E-ISSN: 2582-0192

Received: 05.07.2021

Accepted: 15.08.2021

Published: 01.09.2021

Citation:

Darling Selvi, V., and D. Kalarani. "Time Well Spent Is Not the Time Wasted: A Study from the Pandemic." Shanlax International Journal of Economics, vol. 9, no. 4, 2021, pp. 1-6.

DOI:

https://doi.org/10.34293/ economics.v9i4.4123

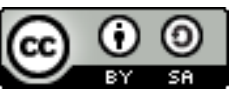

This work is licensed under a Creative Commons Attribution-ShareAlike 4.0 International License

\section{Darling Selvi}

Assistant Professor of Commerce, Research Department of Commerce

Rani Anna Government College for Women, Tirunelveli, Tamil Nadu, India

(D) https://orcid.org/0000-0002-1344-401X

\section{Kalarani}

Full-time Research Scholar

Research Department of Commerce

Rani Anna Government College for Women, Tirunelveli

Manonmaniam Sundaranar University, Tirunelveli, Tamil Nadu, India

\begin{abstract}
The word "quarantine" restricts the movement of people and goods intended to prevent the spread of disease or pests. It is often used in connection to disease and illness, preventing the movement of those who may have been exposed to a communicable disease but do not have a confirmed medical diagnosis. It is distinct from medical isolation, in which those confirmed to be infected with a communicable disease are isolated from the healthy population. Quarantine considerations are often one aspect of control. A distinctive attribute or characteristic possessed by someone or something. "he shows strong leadership qualities." A sample of one hundred and thirty-eight persons was taken for study. The various dimensions of Quality Time on Quarantine Days Were evaluated with the help of an Interview Schedule. The data collected were analyzed with the help of percentage analysis, Factor Analysis, and KMO. The researcher used IBM-SPSS version 20 software for the analysis and interpretation of data. In a recent study, it was found that time was spent on helping with family members regularly, online streaming, involvement in spiritual activities, playing online games and webinars, suffering social media, outdoor games, and watching television for spiritual programs.
\end{abstract}

Keywords: Family, Medical isolation, Online program, Quarantined, Spending time

\section{Introduction}

The concept of quarantine has been known since biblical times and has been practiced through history in various places. In the 21 st century, people suspected of transmitting infectious diseases have been quarantined, as in Andrew Speaker (multi-drug-resistant tuberculosis, 2007) and Kaci Hickox (Ebola, 2014). Moving infected patients to isolation wards and home-based selfquarantine of people potentially exposed was the main way the Western African Ebola virus epidemic was ended in 2016; members of the 8th WHO Emergency Committee criticized international travel restrictions imposed during the epidemic as ineffective due to difficulty of enforcement, and counterproductive as they slowed down aid efforts. The People's Republic of China has employed mass quarantines - firstly of the city of Wuhan and subsequently of all of Hubei province (population 55.5 million) - in the COVID-19 pandemic. After few weeks, the Italian government imposed lockdowns in all the country (more than 60 million people) to stop the coronavirus pandemic. During the COVID-19 pandemic, India quarantined itself from the world for one month. A period during which a vehicle, person, or material presumed of carrying a contagious disease is detained at a port of entry under enforced isolation to check the disease from entering a country. 


\section{Methodology}

To find out the timing spent on quarantine time. This study is confined to quarantine time covid- 19 . The convenience sampling method has been chosen for selecting 138 respondents. Data were obtained from 138 respondents who are using Social media, Whatsapp, and telegram. The sample consisted of both males \& females, who have been contacted personally. A self-designed questionnaire was framed using five-point scales from "No Involvement Less Involvement, Neutral and Involvement, High Involvement" with comparative weights of one to five. Data were collected from students and working professionals. Data collected through the questionnaire is classified, coded, tabulated, and analyzed with the help of the Statistical Package for Social Sciences (SPSS, version 20). The data were analyzed using percentage analysis, factor Analysis and KMO for indicating the Quality Time on Quarantine Days.

\section{Review of Literature}

Dharmendra Kumar, Rishabha Malviya, Pramod Kumar Sharma: Coronavirus causes respiratory infection including pneumonia, cold, sneezing, and coughing, while in animals, it causes diarrhea and upper respiratory diseases. Coronavirus transmitted human to human or human to animal via airborne droplets. Coronavirus enters the human cell through the membrane ACE-2 exopeptidase receptor. WHO and ECDC advised avoiding public places and close contact with infected persons and pet animals. Firstly, Coronavirus (2019-nCoV) was isolated from Wuhan market China on 7 Jan. 2020.

Mattioli, A.V., Ballerini Puviani, M., Nasi, M. et al.: COVID-19 is beginning a global pandemic with a high number of deaths and infected people. To restrain the distribution of the COVID-19 virus, Governments have enforced constraints on outdoor projects or even collective quarantine on the population. One important outgrowth of quarantine is a change in lifestyle: reduced physical activity and an unhealthy diet. Quarantine carries some longterm influences on cardiovascular disease, mainly associated with an unhealthy lifestyle and anxiety. Following quarantine, a global action supporting a healthy diet and physical activity are mandatory to encourage people to return to a good lifestyle.
Pranab Chatterjee, Nazia Nagi, Anup Agarwal, Bhabatosh Das, et al.: A novel coronavirus (nCoV) spillover event, with its epicenter in Wuhan, People's Republic of China, has appeared as a public health emergency of international concern. The review closes with the key learning points from the ongoing efforts to prevent and contain COVID-19. It identifies the need to invest in health systems, community-led response mechanisms, and the need for preparedness and global health security.

\section{Research Gap}

A lot of research is obtaining done on the causes of the effects of the Coronavirus, the need to remain at home and remain healthy, the efforts to prevent the Coronavirus. While people are requested to remain indoors, the importance of whiling away time during the lock-down goes away in return to the age-old games, conventions of study on the Internet, and the field of education has turned to the printed books and the online medium. Research in this field is rare, and steps had been taken to study this point of view and the utility of Social -media during the lock-down period owing to Covid-19.

Table 1 Personal Profile of the Sample Respondents

\begin{tabular}{|c|c|c|c|}
\hline Category & Frequency & Percent & $\begin{array}{c}\text { Cumulative } \\
\text { \% }\end{array}$ \\
\hline \multicolumn{4}{|c|}{ Age } \\
\hline $18-25$ & 67 & 48.6 & 48.6 \\
\hline $26-30$ & 28 & 20.3 & 68.8 \\
\hline $31-35$ & 16 & 11.6 & 80.4 \\
\hline $36-40$ & 13 & 9.4 & 89.9 \\
\hline Above 40 & 14 & 10.1 & 100.0 \\
\hline Total & $\mathbf{1 3 8}$ & $\mathbf{1 0 0 . 0}$ & \\
\hline \multicolumn{5}{|c|}{ Gender } \\
\hline Female & 75 & 54.3 & 54.3 \\
\hline Male & 63 & 45.7 & 100.0 \\
\hline Total & $\mathbf{1 3 8}$ & $\mathbf{1 0 0 . 0}$ & \\
\hline \multicolumn{5}{|c|}{ Occupation } \\
\hline Business & 1 & .7 & .7 \\
\hline $\begin{array}{c}\text { Government } \\
\text { job }\end{array}$ & 17 & 12.3 & 13.0 \\
\hline
\end{tabular}




\begin{tabular}{|c|c|c|c|}
\hline Homemaker & 3 & 2.2 & 15.2 \\
\hline others & 11 & 8.0 & 23.2 \\
\hline Private job & 28 & 20.3 & 43.5 \\
\hline $\begin{array}{c}\text { Research } \\
\text { Scholar }\end{array}$ & 3 & 2.1 & 45.7 \\
\hline Student & 75 & 54.3 & 100.0 \\
\hline Total & $\mathbf{1 3 8}$ & $\mathbf{1 0 0 . 0}$ & \\
\hline \multicolumn{4}{|c|}{ Residential Status } \\
\hline City & 73 & 52.9 & 52.9 \\
\hline $\begin{array}{c}\text { Remote } \\
\text { village }\end{array}$ & 2 & 1.4 & 54.3 \\
\hline Town & 29 & 21.0 & 75.4 \\
\hline Village & 34 & 24.6 & 100.0 \\
\hline Total & $\mathbf{1 3 8}$ & $\mathbf{1 0 0 . 0}$ & \\
\hline
\end{tabular}

Source: Primary Survey

the city, 1.4 percent in Remote village, 21.0 in town and 24.6 percent is living in the village.

Table 2: KMO and Bartlett's test of the Sample Respondents

\begin{tabular}{|c|c|c|}
\hline \multicolumn{3}{|c|}{ KMO and Bartlett's Test } \\
\hline \multicolumn{2}{|c|}{$\begin{array}{l}\text { Kaiser-Meyer-Olkin } \\
\text { Measure of Sampling Adequacy. }\end{array}$} & .838 \\
\hline \multirow{3}{*}{$\begin{array}{l}\text { Bartlett's Test of } \\
\text { Sphericity }\end{array}$} & $\begin{array}{l}\text { Approx. } \\
\text { Chi-Square }\end{array}$ & 1944.618 \\
\hline & df & 406 \\
\hline & Sig. & .000 \\
\hline \multicolumn{3}{|c|}{ Reliability Statistics } \\
\hline Cronbach's Alpha & $\mathrm{N}$ of Items & \\
\hline .922 & 29 & \\
\hline
\end{tabular}

From the sample group, 48.6 percent within the age group of $18-25,20.3$ percent between the age group of 26-30,11.6 percent among the age group of the 31-35,9.4percent age group of 36-40 years, and 10.1 percentage group of above 40 years. 45.7 percent consist of males and 54.3 percent female. The Occupational Status consisting of .7percent business, 12.3percent in government Employment, 2.2 homemaker, 8.0 others, 20.3 percent in private jobs, 2.1 percent in Research scholar, and 54.3 percent involved in Students.52.9 percent stayed in

\section{Source: Derived}

The value of Kaiser-Meyer-Olkin Measure of Sampling Adequacy is 0.838 with the Chi-Square value of 1944.618 for degrees of freedom of 406 and test of significance of 0.000 , which is below the standard of 0.05. Hence Bartlett's Test of Sphericity permits for further analysis of data. A total of 29 statements were taken for study and as per reliability statistics. The reliability statistics for the Quality Time on Quarantine days by the sample 29 statements reveals that the value of Cronbach's Alpha is .922 indicating the adequacy of reliability.

Table 3 Rotated Component Matrix of the Quality Time on Pandemic

\begin{tabular}{|l|c|c|c|c|}
\hline \multicolumn{2}{|c|}{ Rotated Component Matrix } \\
\cline { 2 - 5 } & $\begin{array}{c}\text { Time for } \\
\text { Family }\end{array}$ & $\begin{array}{c}\text { Time for } \\
\text { Entertainment }\end{array}$ & $\begin{array}{c}\text { Time for } \\
\text { Friends }\end{array}$ & $\begin{array}{c}\text { Time for } \\
\text { Exercise }\end{array}$ \\
\hline Helping regularly in cooking & .748 & & & \\
\hline Spending quality time with family members and kids. & .737 & & & \\
\hline Engaging in extra home cleaning activities. & .727 & & & \\
\hline $\begin{array}{l}\text { Doing home chores like washing utensils, mopping, } \\
\text { dusting, etc. }\end{array}$ & .702 & & & \\
\hline Making a new variety of food for family members & .696 & & & \\
\hline Working regularly from home. & .692 & & & \\
\hline $\begin{array}{l}\text { Engaging in hobbies like reading books, crafting, and } \\
\text { painting. }\end{array}$ & .557 & & & \\
\hline $\begin{array}{l}\text { Playing traditional board games physically (chess, } \\
\text { ludo, snake and ladder, monopoly, etc.) }\end{array}$ & & & & \\
\hline
\end{tabular}


International Journal of Economics

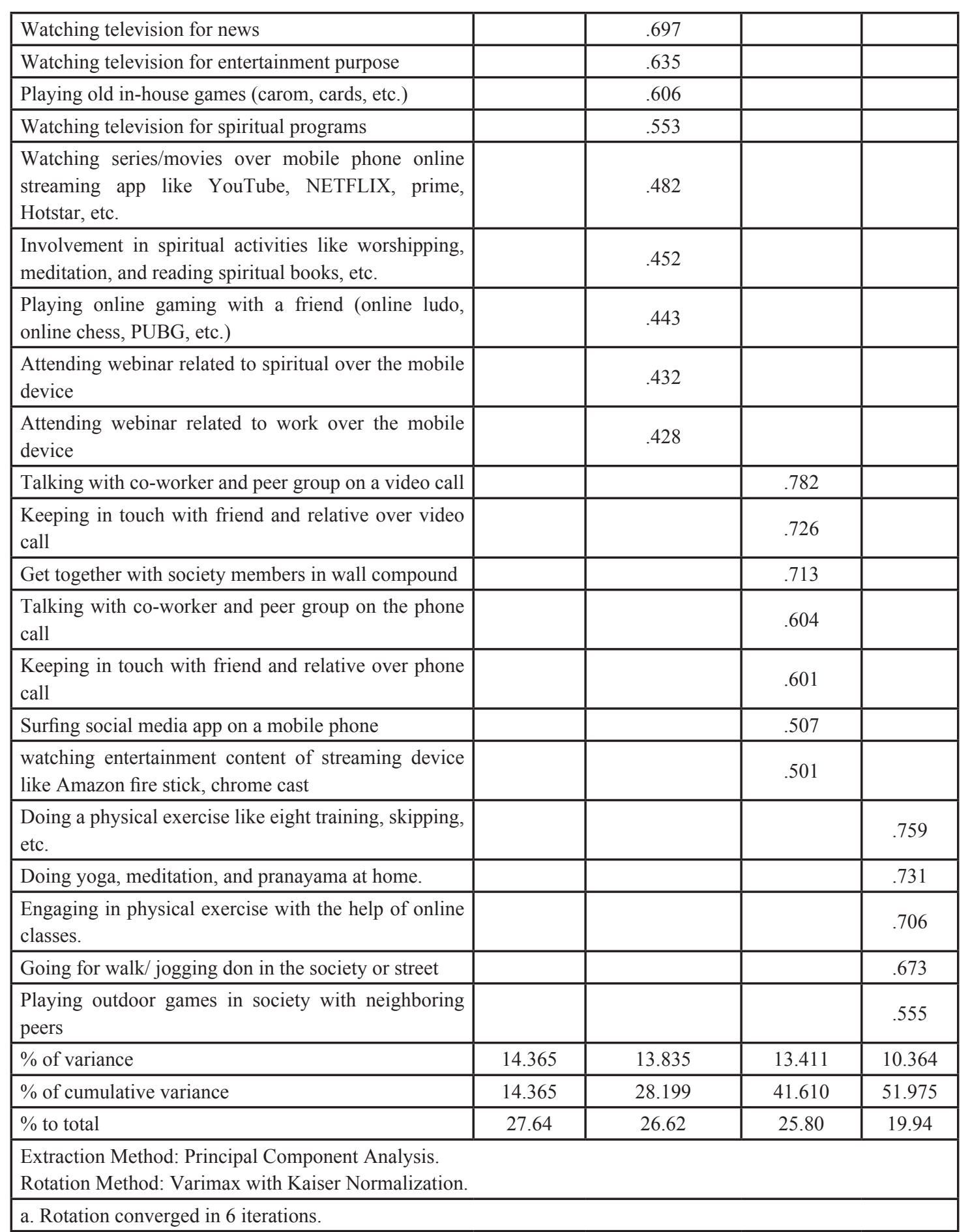

\section{Source: Derived}

\section{Time for Family}

Spending quality time with family members and kids (.797), Engaging in extra home cleaning activities (.744), Working regularly from home
(.716), Doing home chores like washing utensils, mopping, dusting, etc. (.707), Helping regularly in cooking (.699), Making a new variety of food for family members (.628) and Engaging in elf- hobby 
like reading book, crafting and painting(.579). The percentage of variance under this factor is $\mathbf{1 4 . 3 6 5}$ and it forms 27.64 percent out of total.

\section{Time for Entertainment}

Playing traditional board games physically (chess, ludo, snake and ladder, monopoly, etc.) (.711).watching television for news (.697), watching television for entertainment purposes (.635), Playing old in-house games (carom, cards, etc.) (.606), Watching television for spiritual programs (.553), Watching serials/ movie over mobile phone online streaming app like YouTube, NETFLIX, prime, hot star, etc. (.482), Involvement in spiritual activities like worshipping, meditation, and reading spiritual books, etc.(.452), Playing online gaming with a friend (online ludo, online chess, PUBG, etc.) (.443), attending webinar related to spiritual over the mobile device (.432) and Attending webinar related to work over the mobile device (.428). The percentage of variance under this factor is 13.835 and it forms 26.62 percent out of total.

\section{Time for Friends}

Talking with co-worker and peer group on video call (.782), Keeping in touch with friend and relative over video call (.726), Get together with society members in wall compound (.713), Talking with co-worker and peer group on a phone call (.604), Keeping in touch with friend and relative over the phone call (.601), Surfing social media app on mobile phone (.507) and watching entertainment content of streaming device like Amazon fire stick, chrome cast (.501). The percentage of variance under this factor is 13.411 and it forms 25.80 percent out of total.

\section{Time for Exercise}

Doing a physical exercise like eight training, skipping, etc. By elf at home (.759), Doing yoga, meditation, and pranayama at home (.731), Engaging in physical exercise with the help of online class (.706), Going for walk/ jogging don in the society or street (.673), and Playing outdoor games in society with neighboring peers (.555). The percentage of variance under this factor is 10.364 and it forms 19.94 percent out of total.

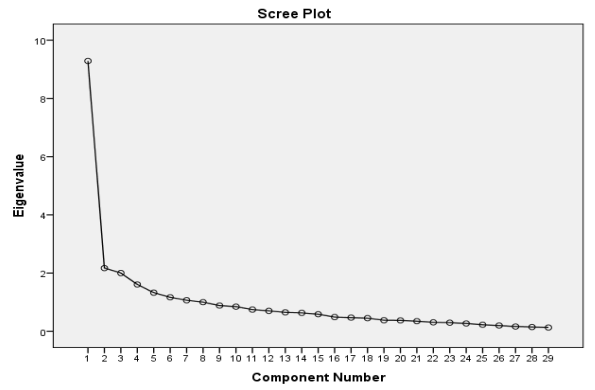

The scree plot shows that eight statements are above the eigenvalue of one and are sloping upwards and the rest twenty-six statements are ranked below the eigenvalue of one and are sloping downwards.

Table 4 Rotated Component Transformation Matrix of the Quality Time on Quarantine days

\begin{tabular}{|l|c|c|c|c|}
\hline \multicolumn{5}{|c|}{ Component Transformation Matrix } \\
\hline \multicolumn{1}{|c|}{ Components } & Time for Family & Time for Entertainment & Time for Friends & Time for Exercise \\
\hline Time for Family & .538 & .548 & .501 & .400 \\
\hline Time for Entertainment & -.720 & -.085 & .608 & .323 \\
\hline Time for Friends & -.331 & .491 & -.606 & .532 \\
\hline Time for Exercise & .287 & -.672 & -.110 & .673 \\
\hline $\begin{array}{l}\text { Extraction Method: Principal Component Analysis. } \\
\text { Rotation Method: Varimax with Kaiser Normalization. }\end{array}$ \\
\hline
\end{tabular}

Source: Derived

The factor Time for Family The factor help related to Time for Entertainment (0.548), Time for Friends (0.501), Time for Exercise (.400). The factor Time for Entertainment is a positive relationship with Time for Friends (.608) and Time for Exercise
(.323) and negative relationship with Time for Family (-.720), The factor Time for Friends. The factor has a positive association with Time for Exercise (.532) and Time for Entertainment(.491). It has a negative association with Time for Family 
(-0.331). The factor Time for Exercise is a positive relationship with Time for Family (.287) and the negative relationship with Time for Entertainment (-.672) and Time for Friends (-.110). Thus, it is inferred that it is the component Time for Family is the base for which impact of covid-19 which lead to Time for Entertainment, Time for Friends, and Time for Exercise.

\section{Conclusion}

Great works of the past have been created during the quarantine time, and even in our country, where the word quarantine is a new term since we are not bound to the word. The work has nothing to do with the migrant workers of our country and we plead forgiveness for not concentrating on them. On the other hand, the study was done with the people who remained at home for more than a month and how effectively they spent the time in a quality manner. It was found that people spent their time helping with family members regularly, online streaming, involvement in spiritual activities, playing online games and webinars, suffering social media, outdoor games, and watching television for spiritual programs. In other words, quarantine has put an end to the mechanical way of our Life in the 21 st century and indeed made man 'Humane.' People were forced to keep themselves away from the mundane world and had an opportunity to go back on the trodden path of the "the Old Family lifestyle. The Study also revealed people spending their time more on Spiritual activities and online programs, which eventually brought suffering. Quality time is spent by many along with their family in Quarantine Time as a result of 90.6 percent people followed the restrictions of the government rules.

\section{References}

Chatterjee, Pranab, et al. "The 2019, Novel Coronavirus Disease (COVID-19) Pandemic: A Review of the Current Evidence." Indian Journal of Medical Research, vol. 151, 2020, pp. 147-159.

Dey, Sushmi. "India Quarantines Itself from the World for a Month to Fight Coronavirus." The Times of India, 2020.

Elphinstone, Brad, and Steven Conway. "Time Well Spent, not Wasted: Video Games are Boosting well-being during the Coronavirus Lockdown." The Conversation, 2020.

Gyan. "Know the Legal Aspects of Breaking Quarantine Order." Research Decoded, 2020.

Kumar, Dharmendra, et al. "Corona Virus: A Review of COVID-19." Eurasian Journal of Medicine and Oncology, vol. 4, no. 1, 2020, pp. 8-25.

Mattioli, Anna Vittoria, et al. "COVID-19 Pandemic: The Effects of Quarantine on Cardiovascular Risk. "European Journal of Clinical Nutrition, vol. 74, 2020, pp. 852-855.

Mayer, Johanna. "The Origin of the Word 'Quarantine'." Science Friday, 2018.

Mckenzie, David. "Measuring How Youth Spend their Time When Schools are Closed." World Bank, 2020.

Ronald, Eccles, and Olaf Weber. Common Cold. Birkhäuser, Basel, 2009.

Statement on the 8th Meeting of the IHR Emergency Committee regarding the Ebola Outbreak in West Africa. World Health Organization, 2016.

"Etymologia: Quarantine". Emerging Infectious Diseases, vol. 19, no. 2, 2013.

"Quarantine." Merriam-Webster, https://www. merriam-webster.com/dictionary/quarantine

\section{Author Details}

Dr. V. Darling Selvi, Assistant Professor of Commerce, Research Department of Commerce, Rani Anna Government College for Women, Tirunelveli, Tamil Nadu, India, Email ID: darlingselvi@rediffmail.com.

Mrs. D. Kalarani, Full-time Research Scholar (Reg. No. 19211171012030), Research Department of Commerce, Rani Anna Government College for Women, Tirunelveli, Manonmaniam Sundaranar University, Tirunelveli, Tamil Nadu, India Email ID: kalajohn12@gmail.com. 